\title{
When will the Daybreak Come? ${ }^{1}$
}

\author{
Popular Music and Political Processes in Ethiopia
}

\author{
Kristin Skare Orgeret
}

\begin{abstract}
Popular musical expressions are important for discourses of citizenship and belonging. Focusing on popular music and political processes in Ethiopia today, this discussion uses Tewodros Kassahun aka Teddy Afro's music as an example. Teddy Afro is a popular voice challenging the prevailing political discourse in Ethiopia. Several of Afro's songs have been banned by the government on radio and television in Ethiopia, but are found to provide alternative sites of political and cultural resistance to the autocratic regime. Reasons for censorship are discussed as well as how music can provide alternative sites of resistance. The findings show that oppressing political expressions may not always kill the ideas, as they may find alternative arenas in the face of obstacles.
\end{abstract}

Keywords: freedom of expression, popular culture, censorship, music, public sphere

\section{Introduction}

Popular culture may have a central role to play in societies where the mainstream media do not allow for freedom of expression. The case in point here is Ethiopia, a country that, throughout the past decades, has seen processes of politics and conflicts in which individuals find themselves caught up, as they may have little or no say in these developments. It is a common assumption that the present government - led by the Ethiopian People's Revolutionary Democratic Front (EPRDF) that seized power through an armed struggle in 1991 - does not reflect the people's will or pursue common rights to any great degree. The current Constitution's Article 29 protects freedom of expression without interference, including the freedom to seek, receive and impart information, as well as freedom of artistic creation (in Gebremedhin Simon 2006). Despite these promising tenets, Ethiopia was recently listed among the ten nations worldwide in which press freedom has deteriorated the most over the past five years (CPJ 2007). Restrictions of freedom of the press are also underlined in the US State Department's report on human rights practices in Ethiopia (2007). During the political elections in 2005, Ethiopia became the second country in the world (after Turkey) in a ranking of countries by number of imprisoned journalists (Solomon Gashaw 2007). In 2006 alone, 18 journalists were jailed for their work - several of them faced the possibility of the death penalty, two foreign journalists were expelled, and the authorities banned eight newspapers and blocked a number of critical websites. Furthermore, Ethiopia is the only country in the world where the government has disrupted the possibility to send and receive SMS messages. 
The present discussion will be centred on how popular musical expressions are important for discourses of citizenship and belonging in Ethiopia today. The main research question is: What is the value of popular culture in general, and popular music in particular, as a vehicle for political resistance? Other questions of interest for the discussion will be: Who has the right to interpret contemporary Ethiopian society and its history? Who has the right to define reality and impose meanings? What forms of resistance can popular music offer? What are the locations of and the routes for popular music and what spaces does it open for transformation and change? What paths can popular music and the reception of it take in the face of obstacles?

The situation of popular music in contemporary Ethiopia is approached through a case study of Tewodros Kassahun aka Teddy Afro's music and the reception of it. The research questions will be discussed from the perspective of DJs on national radio, owners of small, independent music shops in Addis Ababa, and a selected number of listeners through questionnaires, interviews and reception analysis. In an attempt to understand the space that music occupies in the listeners' daily lives, central topics are questions of language, music as opposition, identity, negotiation of meaning and control. To exemplify how popular music can provide alternative sites of resistance, the article proposes a close reading of two of Teddy Afro's songs.

Teddy Afro became an important voice in the national exchange of ideas during the period around and after the 2005 elections. Whereas national Ethiopian television and radio refuse to broadcast several of Teddy Afro's songs and videos, his music nevertheless plays a vital role in constructing patterns of belonging and in processes of negotiating identity, as the songs find other ways to reach their public.

\section{Popular Music as Resistance and Field of Repression}

Popular music, like popular culture in general, is a concept with a double-layered meaning owing to the word popular. The first and most commonly used meaning of 'popular' views music as part of the culture industry in which popular is defined in terms of commercial success. In Ethiopia, local popular music has outperformed its imported rivals in terms of popularity. Whereas newspapers or news talk shows reach mostly an elite section of the population, popular culture is successful in reaching a wide variety of viewers and listeners. Second, the word popular literally means 'of the people', and popular music hence can be referred to as music that concerns itself with issues to do with the existence and survival of 'the people'. Its production is understood as a social interactive process in which the musician on one level speaks to 'the people' and on another level speaks of and on behalf of them (Kwaramba 1997).

According to Stuart Hall (1994: 461), the popular can be defined as those forms and activities in society that have their roots in the social and material conditions of particular classes, which have become embodied in popular traditions and practices. Popular culture is defined in relation to the continuing tension, influence and antagonism of 'the people' in the dominant culture. The definition treats the domain of cultural forms as a constantly changing field. Experiences from other countries have also shown how popular music can be a central part of political struggles. For instance, popular music played a particularly important role in the resistance movement during the Apartheid period (1948-1991) of South African history (Shoup 1997).

It should be noted that music has always played an important role in Ethiopian culture. It is as important as it is diverse. In Ethiopia, music is part of all significant 
movements, from ancient battles, through the periods of Haile Selassie's reign and the Derg regime, to the contemporary situation. Music is important in relation to religion; one can hear traditional songs from the Orthodox Church being chanted by priests at specific times of day both in the cities and rural areas, while other forms of traditional music are influenced by Muslim music. In Ethiopia, traditional music is often considered as popular among youth, as is more modern music (interviews, Addis Ababa 2007).

\section{Teddy Afro, Banned but Everywhere}

Addis Ababa. From big load speakers outside little lopsided music stalls in narrow streets the same rhythms emerge. The many blue minibuses and Lada taxis in the crowded avenues project the same distinguished voice. From coffee houses, markets and outdoor restaurants - the city seems to move to the same tune. Street vendors and shoe cleaners know the lyrics by heart: Emama-Ethiopia, Abyssinia - Ethiopia, Ethiopia - Emama, Ethiopiaye... The sound track of Addis Ababa is performed by Teddy Afro. Afro is banned, but everywhere. (From researcher's field notes, January 2006)

Teddy Afro aka Tewodros Kassahun is the young singer and writer who has been said to bring the Amharic ${ }^{2}$ language back to Ethiopian youth. His music often has a connection to reggae, and as a result Teddy Afro is commonly referred to as Ethiopia's Bob Marley. Afro's second album Yasteseryal (It Heals) sold more than a million copies in a few months after its release in 2005, and became the biggest selling Ethiopian music album ever. The album's 14 tracks ${ }^{3}$ once again proved Afro's extraordinary talent for timing. Afro/ Kassahun had already shown his aptitude for liking up with major Ethiopian moments in a highly appropriate manner several times before. He was timely in acclaiming the legendary athlete Haile Gebre Selassie, and the emerging star Kenenisa in Tarik Tessera (History is Made), right after Kenenisa and Haile came in first and fifth, respectively, in the $10,000 \mathrm{~m}$ race at the 2004 Olympics in Athens. Furthermore, for the $60^{\text {th }}$ posthumous birthday anniversary of Bob Marley in Meskel Square in Addis Ababa in February 2005, Afro participated with Shashamene ${ }^{4}$, another ad hoc single, which went straight into the mood of the moment: "Promise...Rita Marley, Promise Ziggy Marley to bring his body!".

At the release of the long awaited album Yasteseryal, right at the time of the 2005 election, Teddy Afro further emphasized his sensitivity to presenting the right songs at the right time. The 2005 elections were surrounded by many expectations and represented a landmark in terms of voter turnout. For the first time in history, there was a real television debate in the period leading up to the elections. The period represented more openness, but was also characterized by more sensationalism in the media, particularly in the blooming private press. Against this setting, Yasteseryal appeared and summarized the history of the past fifty years of Ethiopia. The songs are about love, forgiveness and unity. They describe an embattled nation in search of new directions and repeatedly stress the need to improve and change the country. The timely launch of the album gave proof both of a strategist who knew the rules of the cultural industry and his market and of the work of a potential national poet. Two radio DJs expressed in interviews how the album consolidated Teddy's position as a national bard:

Teddy Afro is very aware of what is going on in the nation, more aware than any other artist (interview, DJ 1 2007) 
Yasteseryal exhaled my expectations in every way. The synthesized sound use although present, the level of detail and songwriter-ship makes it tolerable. Sometimes the cheesy sound clips give the album a comical relief from the deep national trance it puts you in to (interview, DJ 2 2007)

After the general elections in May 2005, the optimistic prospects for more openness expired as a range of serious human rights abuses occurred when the opposition parties Coalition for Unity and Democracy (CUD) and United Ethiopian Democratic Forces (UEDF) refused to accept the announced results ${ }^{5}$. Protests against the election results, led by the opposition party CUD, began in November 2005 and resulted in several thousand people being arrested and at least 42 demonstrators and a number of policemen being killed. The reactions to the unrest that followed the May 2005 elections led to severe obstacles to the freedom of expression in Ethiopia. Shortly after Yasteseryal's release, the Ethiopian state broadcaster banned many of its songs and videos. While songs were often banned because of their lyrics, one of the interviewed radio DJ's who experienced the banning also saw it in direct relation to the living images.

The videos - there was just no way they were going to play the video on TV. The video is sometimes much more controversial than the song, but played a part in having the song banned from radio (interview, DJ 2 2007)

On the other hand, banning is perhaps not an adequate term, as no restriction was officially made, but the songs were nevertheless prohibited from being played on the radio. Through the interviews with radio DJs, it became clear that, in Ethiopian radio, banning was more on the level of notices pinned in the studio prohibiting the broadcasting of certain songs. One DJ from Ethiopian Radio described how it worked in the following:

One would post a notice in the studio: these songs should not be played. When it came to Teddy Afro no notice was posted however, in that case people in the studio would tell you directly (interview, DJ 3 2007).

Another source, however, stated that there was a list of definite names of singers and titles of songs that should not be played; this list had been distributed to Ethiopian Radio staff members, and several of Afro's songs figured on it.

The fact that there is no open discussion about the need for banning may be a way to 'censor the fact of censorship'. According to Jansen and Martin (2003), the first and most obvious method to make censorship work is to try to reduce awareness that censorship has occurred. For example, when controversial works are submitted to the governmentcontrolled radio and television channels, it is easy to reject them on the grounds that they are not of sufficient calibre or that they lack artistic quality. It is, however, difficult to use the argument of 'market censorship' or lack of popular demand in relation to the most popular album in Ethiopia, ever.

The notion that censorship of music could have a massive impact by deterring enlightenment came up often in my 2007 interviews. One interviewee said that the banning was very interesting, because it gave you a clear idea about what the Government likes and dislikes, more so than do more shallow, ready-made statements. Another interviewee probably reflected a view closer to the Government's own by arguing, on the contrary, that one could not talk about banning or censorship in the Ethiopian context at all. Some songs "are simply not played by ETV or radio, that is very different" (Interviewee, February 2007). The latter argument feeds directly into the discussion linked to the difference between banning and not playing. 
Documentation of the existence of banning is essential to opposing banning; otherwise it would be difficult to prove that censorship has occurred at all. It is often impossible to find direct evidence, primarily because the censor has to cover the actions in legitimate terms. Furthermore, given that all legal broadcasting in Ethiopia takes place under government control, overt acts of censorship are unnecessary. As seen above, in the case of Ethiopian radio, somebody may say 'Please do not play those songs', but there might be no official restriction, and thus the banning is harder to prove. The existence of censorship may itself be censored through threats. In interviews with radio DJs, it became clear that self-censorship was widespread within the national radio, and there were numerous subtle ways in which DJs were discouraged from playing songs (assumed to be) critical of the Government.

One way to reveal censorship is to expose double standards. On the occasion of a concert at the Sheraton Hotel in Addis Ababa on the Ethiopian New Year's Eve, 10 September $2005^{6}$, Teddy Afro himself revealed such double standards. Afro was invited to sing, but was told not to sing certain songs, such as Yasteseryal. Teddy Afro refused to entertain under those conditions and walked away from a deal, which according to the local press was worth over 130,000 Birr, or around 14,000 USD.

Jansen and Martin described how a standard method for justifying censorship is to attack the censored. A censored author, for example, might be castigated as incompetent, immoral, disloyal, unreliable, unstable, paranoid, or greedy (2003: 9). On 4 November 2006, Teddy Afro was arrested, apparently for bad driving and a hit-and-run accident involving an 18-year-old street boy. He was released shortly after on 50,000 Birr bail. Most of the people interviewed saw this as a trivial error or even as a constructed case that was used by government media as a rationale for discrediting the artist and his work. If, as many of my interviewees argued, Afro was an innocent victim in this case, this episode can be seen as an example of censorship through intimidation.

Can a government legitimately prohibit citizens from certain types of popular culture such as listening to certain sorts of music, or does this constitute an unjustified violation of basic freedoms? This question lies at the heart of a debate that raises fundamental questions about when, and on what grounds, the state is justified in using its coercive powers to limit the freedom of individuals.

\section{Reasons for Censorship}

Censorship, in the form of control of the information and ideas circulated within a society, has been a characteristic feature of dictatorships throughout history. Censorship occurs to varying degrees and goes back to ancient times. Every society has customs, taboos or laws that to some degree regulate individuals' behaviour. As a result, individuals perform a kind of self-censorship, and such restraint can be seen as part of the efforts rational human beings undertake to participate in society and to enforce the prevailing conventions.

Also in societies mainly referred to as 'democratic', censorship is common under certain circumstances, often under the pretext of protecting three basic institutions of society: the family, the church or the state. Martin Cloonan (1996) investigated the ideas and policies that led to censorship of music on Great Britain's BBC Radio 1. Whereas most songs were banned for promoting promiscuity, there was also a range of songs that were banned for clearly political reasons. During the first Gulf War, the BBC Radio training unit submitted a list of controversial records that became an unofficial list of 
music to ban in British prime-time broadcasting ${ }^{7}$. During the Falkland war, more indirect musical censorship happened as local $\mathrm{BBC}$ radio DJs were asked to think carefully before playing songs such as Elaine Page's “Don't Cry for Me, Argentina” or Split Enz' "Six Months in a leaky Boat", particularly close to news bulletins on the war.

National security, and increasingly also global security, has been and is an important rationale for suppression of information and ideas. The more difficult or challenging the national situation is perceived to be, the easier it seems to be for governments to justify actions to control the information and ideas people receive.

Liberals, however, will defend a strong belief in the concept of individual freedom, and against any regulation that interferes with that freedom. The only grounds that liberals typically regard as providing a legitimate reason for state restrictions on individual freedom is in order to prevent harm to others. To convince a liberal that free speech should be restricted, it should be proved that the utterance in question causes significant harm to others: either in a way corresponding to a narrow definition of 'harm', that is actual physical violence to others, or in relation to a broader, more interest-based conception of 'harm', that is that the expression violates important interests or rights of others (see, e.g., Dyzenhaus 1992, Feinberg 1987). The latter more interest-based right to protect people against harm became highly relevant in the debate following the so-called Mohammed cartoon case in 2006.

An integral aspect of the discussion on reasons for censorship is the theoretical arguments for free speech. The initial purpose of free speech was to empower the people with the use of their own minds, common sense and compassion and to use this to 'govern' the public realm. Today, the three most common justifications for the use of free speech in society are: the importance of open discussion to the discovery of truth; each individual's right to self-development and fulfilment, as restrictions on what we are allowed to say, write, hear or read inhibit our personality and its growth; and that public discussion is a political duty and a fundamental principle of democratic governance (Barendt 2005: 7-18).

The banning of Teddy Afro by Ethiopian radio and television can be understood in light of the argument that one of the main types of triggering factors for human rights violations in Ethiopia under the EPRDF government has been civilian display of protest (Tronvoll 2007). In the case of Teddy Afro's Yasteseryal album, several of the songs became lucid examples of a popular voice challenging the ruling political discourse. To a certain degree, the singing of/listening to a song could be seen as an opportunity to demonstrate one's support for the opposition. Resistance can take many forms, depending on the severity of state oppression. Although some of the texts, at least from an outsider's perspective, do not seem very radical or politically challenging, the songs apparently hit a national nerve at a decisive moment in Ethiopian history. The symbolic value of the songs was probably as important as a source of popular and political resistance as were the actual lyrics.

\section{The Music Shops as an Alternative Public Sphere}

If we are to approach popular music's place in society, in Ethiopia just as anywhere else in today's world, we must explore how the main culture industries and media institutions distribute it, but we also must attempt to understand the place music occupies in the listener's daily lives. 
In spite of being banned or at least 'not played' by the public broadcaster, Teddy Afro still rules the streets of the capital and the countryside pathways of Ethiopia. In their article "Making censorship backfire", Sue C. Jansen and Brian Martin (2003) discussed how attempts at censorship occasionally lead to far greater awareness of the target than would have occurred without the interventions of censors. They suggest, that

attempts to repress 'dangerous ideas' sometimes have the opposite effect: that is, they serve as catalysts for expanding the reach, resonance and receptivity of those ideas (2003:5).

In line with this argument, several of my interviewees emphasized that the banning of a song could bring about an opposite effect of suppression, as it brought more attention to the song:

The banning often makes people more curious to know the song. Look what happened to Yasteseryal. People were so interested in hearing the song that they were queuing to buy the cassette (Interviewee, February 2007).

Furthermore, based on observations and interviews carried out in five small music shops in the area of Casa Inches in Addis Ababa in February and June 2007, it turned out that in addition to such a possible 'opposite' effect, the small music shops played a vital role in serving as 'narrow casters' and load speakers for Afro's music. The music shops studied were usually owned by a man who had one or a few shopkeepers to help him at different times in the shop. A typical shop is only a few square meters in area, built of simple wood materials and covered from floor to ceiling with copies (both legally and illegally copied) of CDs and DVDs as well as with posters of local and international stars.

There are sometimes five-six persons inside the shop at the same time, mostly young people. It is a bit crowded, but it is ok. We discuss music, fashion, music, politics and music. Here we are free to speak our mind (Music shop assistant 1, interview 2007)

Hence, the tiny music shops not only promote the music they sell by playing it through big load speakers, but they also represent a place where the topics raised by the songs' lyrics can be commented upon, further developed and discussed. This was very much the case with Teddy Afro's music.

There is little creative criticism in Ethiopia. It was a big event when Yasteseryal was launched. A big event! For weeks and weeks we only played that CD. Teddy's songs opened new fields of discussion, and of course it happened in the period of the elections, so the two events went hand in hand (Music shop owner, interview 2007).

He [Teddy Afro] provided us with new tools to carve our reality. He provided us with new images, or rather, he opened our eyes to images that had been there right in front of us all the time, as the metaphor of the church and the mosque in Markato (in Shemindefer). He showed us an alternative way seeing and from there we can discuss, agree or disagree (Interviewee, 2007).

This article only looks into the role these small shops play in one popular area of Addis Ababa, but it is assumed that they may play a similar role around the nation. Based on calculations from 2003, 57 percent of the population in Ethiopia, over 15 years of age, is illiterate (Gebremedhin Simon 2006). The findings from interviews and observations 
in the music shops show that popular music can play a vital role as a storyteller for these groups of the population too.

Some of the people who come here frequently do not buy anything, but come here to listen to music and to discuss. We can talk about different thing from gossiping to serious political issues - well that is gossiping too perhaps, because the media never tell what is really happening. But we talk about the things that we think should change (Music shop assistant 2, interview 2007).

Whereas a central criterion for the traditional Habermasian public sphere was that people came together as citizens and not as customers, the present study of the small music shops in Addis Ababa exemplifies that it is not always possible or appropriate to separate citizens from customers. People come to the music shops sometimes as customers, sometimes as citizens, and sometimes as both and use the space provided by the shop as a sort of alternative public space. Here the background and identity of the participants is not important, as long as one allows others to express themselves freely. The observation showed that although the shops are driven by commercial principles - the aim being to sell the CDs and DVDs they display - they also, to a certain degree, respond to the wish for a differentiated and pluralistic public space (as it has been described by, e.g., Benhabib 1992; Dahlgren 1995). As in most public areas in Ethiopian society, women were in minority also here, but several young women nevertheless said that they liked to take part in the discussions unfolding in the music shops and stressed that female singers, for instance Aster Aweke, have been important in giving women more space on the Ethiopian popular cultural arena (interview, 2007).

The small music shops seem to offer an alternative arena of expression and discussion in a situation where the traditional media are hardly able to serve as a platform for free discussions. One main weakness of this alternative public space is, of course, that it does not communicate with the state. However, if we follow the reasoning of Kimini Gecau (1996), who showed how songs that take the form of narrative may approximate a kind of oral journalism, we might argue that this is the case with Teddy Afro's songs and that the small music shops provide the medium of communication. In a commonsensical manner, the singer mobilizes a variety of methods to describe Ethiopian society and communicate its people'shistories. In the interviews, it became clear that different listeners perceived Teddy Afro's texts as reconfirming the meanings they have made out of their daily activities in the context of social relations of power and inequality (interviews Addis, May 2007). Thus, in a socially conscious manner, the music can be used as a vehicle for conveying messages and may play a role in fragmenting and contesting political authority.

\section{Teddy Afro's songs}

In order to get a better impression of how Teddy Afro's songs have been important in launching discussions and how they act as popular resistance to a more restricted set of ideas, this part of the article will look more closely at the lyrics of two of Afro's songs, Yasteseryal and Shemindefer ${ }^{8}$.

The songs have been selected somewhat randomly, based on impressions from interviews and conversations indicating that they were both important to many listeners. It also appeared that these two songs had been central in launching various discussions, for instance in the music shops in Casa Inches. 


\section{Yasteseryal}

Yasteseryal is the title song from the album launched in 2005 and became the most important song during the election period. The song begins with a description of the disgraceful downfall of the Emperor Haile Selassie, passes through the 17 years of military domination under the Derg, marred with massacres and exiles, and ends with the period of the current Ethiopian rulers. Yasteseryal pronounces a popular understanding of the 'new' politicians as similar to the old ones. Leaders have changed, but revengeful killings and detentions never ceased - the politicians only change seats, while nothing changes in the real battle for the country's poor:

The Derg militia dressed in their warrior cloths,

they took the seat to bring change

But like the previous leaders they

punished the past leaders.

We only see leaders changing seats, but no development.

In this way, the lyrics negotiate dominant definitions and propose a sense of 'we-ness' among the listeners as opposed to the 'others' - the leaders - who are all more or less the same. Through this negotiation, the song may invite listeners to reflect on the dominant groups in society and open themselves to new readings and new ideas. Perhaps it is the refusal to conform to a single idea of what contemporary Ethiopia is and should be that indicates what is peculiarly 'popular' in Teddy Afro's songs. Afro sings in Amharic, but the texts allow a broader understanding of the national than what the largest ethnic culture has defined it to be. For instance, the title of the song Kab Dahlak, on the same album, comes from the island of Dahlak in the Red Sea, which is now under Eritrean sovereignty, and refers to the Ethio-Eritrean divide through a metaphor of the fracture of a family. The lyrics of Yasteseryal propose a negotiation of the meaning of contemporary Ethiopia as they openly interrogate and oppose official truths.

The land is fertile, and we have all

It was because there was no love

that we are punished by hunger and can't survive

But if we stand together and work hard

It will not be long before Ethiopia becomes powerful again

The theme of unity and forgiveness runs through the lyrics of Yasteseryal, which literally means 'it heals':

Revenge is not good - Emama

It will disconnect us from God in the end

Abyssinia - Emama

Living together in love will protect us from any danger

Oh! Yasteseryal.

The song's lyrics stress the need to bring people together and to re-establish peace and brotherhood, as the word Yasteseryal repeated over and over again constitutes the core of each refrain. Afro refers to the prime example of reconciliation on the African continent, the socially sanctioned icon of peace, namely Nelson Mandela:

Forgiveness to Ethiopia

A walk to freedom

(...) 
Osisa Osisa Osisa Mandela

Like he reconciled the opponent parties

Let different parties stand together

Let us keep God's word loving each other

Take the plough up and forgive one another

It is in the lyrics of Yasteseryal that we find the most direct connection to the political elections:

When one party blames the other

When that critic is in the air

We people are confused to choose the best leader

Yasteseryal would seem to be successful in demonstrating popular resistance to the political hegemony, as it repeats the need to open up the discourse and include concepts of forgiveness and inclusion. The lyrics also refer to the pandemic of HIV/AIDS that afflicts Ethiopia, but that is often ignored in the public discourse:

My people is dying of fire!

Part of the complex nature of the song is how well it fits the concept of 'layering'; the subtler the hint, the more numerous the layers of meaning will often be.

When will the daybreak come?

This is popular music as resistance to political hegemony. The lyrics can be seen as a way of deploying symbolic forms to define relations with the political leadership. As also became clear through the interviews in the Addis Ababa music shops and among students, Afro's music allows negotiation of dominant meanings and may create alternative meanings that make manifest the relevance of political struggle.

\section{Shemindefer}

The lyrics of the song Shemindefer also emphasize the need to work against the classic divisions in Ethiopian society and in the world as a whole. It is quite explicit about its aim to promote unity and understanding in the highly multicultural society Ethiopia is. The country is both multi-cultural and multi-lingual, with close to 80 indigenous languages.

Shemindefer, which is Afro's take on the French words 'Chemin de Fer' (railway), is about the love between a Muslim man and a Christian woman. The lyrics of Shemindefer can hence be seen as part of a popular resistance to cultural and religious taboos. The majority of Ethiopians identify themselves as either Christians (Ethiopian Orthodox, Protestant, Catholic) or Muslims (Gebremedhin 2006). According to estimates, between $45-50 \%$ are Muslims, followed by $35-40 \%$ who are Coptic Ethiopian Orthodox, $12 \%$ who are animists and the remaining 3-8\% belong to other faiths (CIA, 2006).

The Christian orthodox St. Raguel Church and the Muslim Anwar Mosque are situated face to face next to the big market Markato in Addis Ababa. In Shemindefer's powerful metaphor, the prayers from both holy locations reach the same destination:

In Shegerr, Addis A'ba, your own home town, indeed;

Does Raguel Church not face Anwar Masjid?

Though parted by a mere mortal fence;

In concert to the skies their prayers rise, and hence; 
Both the church's Qidassie and the mosque's Azaan, The Creator hears them - in symphony - as one.

Hence, in the music shops, the lyrics of Shemindefer feed into discussions of differences, of world terrorism and of religious taboos. Some of the interviewees even argued that the lyrics have had a direct effect on listeners, as a significant increase in the number of marriages between people of various faiths occurred throughout Ethiopia at the time of its release. The City Hall of Dire Dawa in South Eastern Ethiopia reported an unusually high number of marriage license applications being submitted within weeks of the release of Teddy Afro's new album:

We are working overtime to meet the high demand and handing out marriage licenses for people marrying a partner of a different faith. The album [Yasteseryal] seems to have an effect. (Mustafa Woldeselassie, Family Issues Department, Dire Dawa City Hall. Quoted in Ethiopis.com, 4 July 2005).

It is hard to tell whether Teddy Afro was once again clever in taking the national pulse by describing a popular trend before anybody else, or whether the increased number of cross-religious marriages was in fact influenced by Shemindefer, as the representative of Dire Dawa City Hall seemed to believe. Perhaps the cross-faith weddings were both an inspiration to,and inspired by Afro's lyrics. All the same, Afro is right in arguing that Ethiopia indeed is a country where people of different religious backgrounds have coexisted in peace for thousands of years:

The age-old haven Our Ethiopia has been;

Where Muslims and Christians have long lived in love, as kin

The possibility for Muslims and Christians to live happily together is not least an important argument in our current global world. Teddy Afro's lyrics echo the argument claiming that a great deal of the new thinking about Islam is not taking place as much within the traditional realms of religious authority as within popular culture (e.g. Eickelman and Anderson 2003; Pond 2006). Kjetil Tronvoll (2007) emphasized that any statement indicating a correlation between ethnicity and human rights violations in today's Ethiopia will be considered highly provocative by the current Ethiopian Government. He links this to Ethiopia's historical background:

This is based on the reality that the leading party in the EPRDF ethnic coalition government the TPLF (Tigray Peoples Liberation Front) fought a 17-year long armed struggle against the Derg military junta with the objective to achieve political-cultural recognition and to re-establish governance accountability in relation to collective ethnic group rights in Ethiopia (2007: 6).

A closer look at the lyrics of Teddy Afro shows us how Afro, through his musical work, proposes that there are alternative answers to those being provided by the ruling regime concerning who has the right to define the society we live in.

\section{Conclusion. Music and Belonging}

Two points emerge from the above discussion. First, the enormous response to Afro's songs clearly shows the public's appetite for music that voices alternative stories and their desire for stories that involve different voices and different truths. This stresses how music lies at the heart of people's culture and sense of belonging. The second point 
is that oppressing political expressions may not always kill the ideas, as they may find alternative arenas and roads in the face of obstacles.

It turned out that banning or "not playing" Teddy Afro in the national media did not make him less popular among the public. A total of 114 students at Addis Ababa University responded to a questionnaire with open-ended questions designed for the present study in February 2007. A majority of 67 percent of the students asked mentioned Teddy Afro among their favourite singers or as the favourite singer ${ }^{9}$. The notion that Ethiopian youth increasingly prefer music with texts in Amharic came up often in the interviews. This was supported by the questionnaires, as 57 percent of the students answered that they preferred listening to music with text in Amharic, 36 percent said they liked both languages equally, whereas only 7 percent preferred music with English lyrics.

When asked what music means to Ethiopian culture, the answers from the students were many and varied. Some stated simply "Everything", while others said:

- Music is part of us. We all use it to express our inner feelings.

- It is a reminder of the past and the only way to express belonging.

- It means unfolding the values of various ethnic groups in the country.

- It is the manifestation of culture itself!

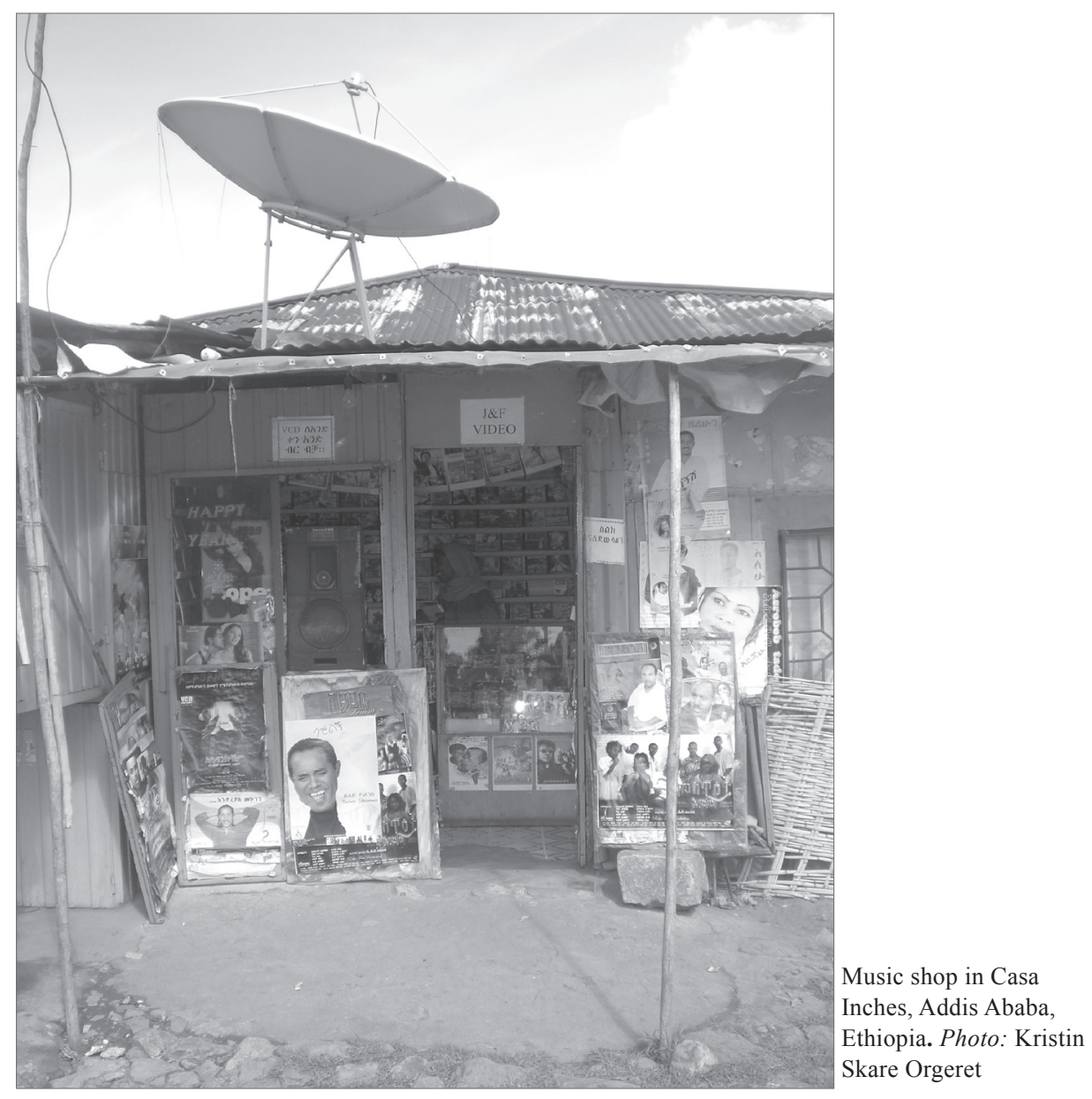


Asked whether banning of popular music had an effect on the public, most of the students argued that yes, it did have an effect. Some of the responses were:

- Yes. It unnecessarily polarizes the public against the government.

- It violates freedom of speech.

- It undermines the society's need for change and reform.

The data obtained from the questionnaires strengthened and developed the findings from the interviews and observations in the Casa Inches music shops and among the radio DJs. Seventy-nine percent of the students said they knew the title/s of one song/several songs banned by the ETV or Ethiopian radio. Very interestingly, 100 percent said they listened to some of these songs anyway. When asked about where they listened to these banned songs, the answers varied, including 'at home', 'in taxis', 'in music shops', 'in cafés and cafeterias', 'in public places, hotels and nightclubs'. One student even responded 'anywhere else than ETV and Ethiopian radio' and another 'whenever and wherever possible'. 'At home' was the most frequent answer, however, and a few students added 'locking up my door' or ' privately', while 'in taxis' and 'in music shops' shared the ranking as the second most popular location for listening to popular music that was banned by the national broadcaster.

Popular culture occupies a key position in identity formation, processes of empowerment, and in the construction of belonging among people of contemporary Ethiopia. The discussion above identifies some reasons for musical censorship or control and illustrates how popular music can provide new sites of resistance. Some examples of how people relate to censored music have been given. We have seen illustrations of how people, in times of suppression, may find new places where relevant issues can be discussed and new meanings can be negotiated. Keyan Tomaselli (2007) argued that the exigencies of being 'under fire' make it hard to find the discursive space in which participants can catch enough breath to speak the truths of their own participation. At best, the small music shops of Addis Ababa provide such a space, in which people can catch their breath and alternative approaches to reality can be discussed and created.

\section{Notes}

1. From Tewodros Kassahun's Yasteseryal.

2. Amharic is Ethiopia's official language and the most widely spoken language in the country. Around 41 percent could speak the language at the time of Ethiopia's last census in 1994 (Gebremedhin 2006).

3. The album's tracks are Yasteseryal;Alamn Alena; Shemendefer;Ker Yhun; Kabdahlak; Lay Say (Bel Stegn); Lambadina; Etege; Lemin Yihon; Ngeregn Kalsh; Semi Leleh (Afe); Promise: Balderasu and Seleme.

4. Shashamane, about $250 \mathrm{~km}$ from Addis Ababa, is the hometown of many Rastafarians in Ethiopia and is, apparently, where Marley wished to be buried.

5. Early results had shown the opposition with a great lead, sweeping all of the contested seats in the capital Addis, in the race for both parliamentary and local government. The vote tallying process, however, was ordered to stop when, during the evening of May 16, Prime Minister Meles Zenawi declared a state of emergency, banned any public gathering and replaced the capital city police with federal police and Special Forces drawn from elite army units. On August 9, official results were released, acknowledging that EPRDF had won 296 of the total 524 seats - about 56 percent - enabling it to form a government. In the middle of October, a draft report of a public inquiry into election-related unrests concluded that 193 unarmed civilians were killed and 763 injured during demonstrations.

6. Ethiopia follows the Geez calendar (close to the Julian calendar) with thirteen months, and the first day of a new year is on September the $11^{\text {th }}$ (or $12^{\text {th }}$ every fourth year). Depending on the time of year, the Geez calendar will be 7 to 8 years after the Gregorian/Western calendar, and the Ethiopian millennium change 
is hence celebrated on $11^{\text {th }}$ September 2007.

7. As Cloonan (1996) argued, if the background were not so serious, it would be hard to take the list seriously. The list of banned songs comprised titles such as Roberta Flack's "Killing me softly", Cher's "Bang Bang, my baby shot me down" and Bob Marley's "I shot the sheriff".

8. Translation from Amharic by Eyayu G/Selassie.

9. Also Aster Aweke, Ephrem Tamiru, GiGi, Johnny Ragga, Telahun Gessesse, Mahmoud Ahmed and Solomon Tekalign were frequently mentioned among the students' favourite musicians. A few respondents stated that they were not so interested in secular music, but preferred spiritual singers such as Tesfaye Gabiso, Tamirat and Mihiret.

\section{References}

Barendt, Eric (2005) 'Why Protect Free Speech?' Chapter 1 in Freedom of Speech. Oxford: Oxford University Press, p. 1-38.

Benhabib, S. (1992) 'Models of Public Space', in C. Calhoun (ed.). Habermas and the Public Sphere. Cambridge: The MIT Press.

Cloonan, Martin (1996) Banned - Censorship of Popular Music in Britain 1967-1992. Ashgate Pub Co.

Central Intelligence Agency (CIA) (2006) The World Factbook - Ethiopia. Retrieved June 2007, from https:// www.cia.gov/cia/publications/factbook/geos/et.html\#Econ

CPJ (Committee to Protect Journalists) (2007) 'Backsliders, the Ten Countries Were Press Freedom Has Most Deteriorated’. Special Report 2007, www.cpj.org/backsliders/index.html

Dahlgren, P. (1995) Television and the Public Sphere: Citizenship, Democracy, and the Media. London: Sage.

Eickelman, Dale F. and Anderson, Jon W. (2003) 'Redefining Muslim Publics in Eickelman D.F. and Anderson, J.W (eds) New Media in the Muslim World, $2^{\text {nd }}$ ed. Bloomington: Indiana University Press.

Ethiopia Country Report on Human Rights Practices 2007, US State Department.

Gebremedhin Simon Gebretsadik (2006) Ethiopia, Research Findings and Conclusions. African Media Development Initiative. BBC World Service Trust. London.

Gecau, Kimani (1996) 'The World has no Owner: Everyday Resistance in Popular Songs of Africa', in http:// www.wacc.org.uk/wacc/publications/media_development/archive/1996_2/the_world_has_no_owner_ everyday_resistance_in_popular_songs_of_africa

Hall, S. (1994) 'Notes on Deconstructing the Popular', in Storey, J. ed., Cultural Theory and Popular Culture: A. Reader. New York \& London, Harvestor Wheat Sheaf.

Jansen, Sue Curry and Martin, Brian (2003) 'Making Censorship Backfire', in Counterpoise, vol 7. no 3, July 2003, pp. 5-15. Gainsville: Civic Media Centre.

Korpe, Marie (2004) (ed) Shoot the Singer! Music Censorship Today. London, New York: Zed Books.

Pond, Christian (2006) 'The Appeal of Sami Yusuf and the Search for Islamic Authenticity'. TBS Journal no16, 2006, http://tbsjournal.com/Pond.html

Shoup, J (1997) 'Pop Music and Resistance in Apartheid South Africa', in Alif. Journal of Comparative Poetics 17, pp. 73-97.

Solomon Gashaw (2007) 'Human Rights and Ethnic Federalism in Ethiopia', paper presented at the 16th Internat. Conference in Ethiopian Studies. Trondheim July 2007.

Tomaselli, Keyan (2007)'Introduction', in Critical Arts, Under Fire Edition. University of KwaZulu-Natal.

Tronvoll, Kjetil (2007) 'Human Rights in Federal Ethiopia: The Ethnic Factor', paper presented at the 16th Internat. Conference of Ethiopian Studies, Trondheim, July 2007.

\section{Newspaper articles}

'Teddy Afro's New Song Sparks Flood of New Marriages', in Chewata, www.ethiopis.com, 4 July 2005.

'Teddy Breaks up Sheraton Deal', in Addis Fortune 24. September 2006.

'Police release Teddy Afro on 50000 Bir Bail', by Wudineh Zenebe, in Addis Fortune, 7 November 2006.

\section{Acronyms}

CPJ Committee to Protect Journalists

CUD Coalition for Unity and Democracy

EPRDF Ethiopian People's Revolutionary Democratic Front

UEDF United Ethiopian Democratic Forces 